\title{
Společné vývojové tendence stř̌edoevropského regionu jako předmět historické sociologie
}

\author{
STANISLAV HOLUBEC* \\ Common Developmental Tendencies of the Central European Region as an Object \\ of Historical Sociology
}

\begin{abstract}
The article deals with the idea of Central Europe and aims to identify common developmental tendencies of the region in the medieval period and early modern age. The author emphasizes the advantages of the comparative approach primarily in the case of the medieval and early modern Polish, Czech and Hungarian states. Alongside common developmental tendencies the author emphasizes also important differences which cast doubt on the very idea of Central Europe.
\end{abstract}

Key words: Central Europe, developmental tendencies, medieval period, comparative approach, historical sociology.

\section{Úvod}

V následujícím textu se pokusím poukázat na některé společné trendy a zároveň odlišnosti ve vývoji středověkého a raně novověkého českého, polského a uherského státu a budu se snažit zodpovědět otázku, je-li prostor definovaný těmito státními celky užitečnou kategorií pro historickou sociologii právě při zkoumání evropského středověku a raného novověku. Vývojových podobností regionu nazývaného běžně střední nebo středovýchodní Evropou si zvláště po roce 1945 povšimla celá řada historiků, zejména těch pocházejících z této oblasti, a v minulých desetiletích vzniklo na toto téma několik pozoruhodných prací. Naopak západní historická sociologie tento region jako jednotku analýzy opomíjela. Její klasikové se obvykle zabývali západem Evropy definovaným v hranicích studené války a Východ ponechávali stranou (Norbert Elias [1939], Charles Tilly [1992], nověji třeba Michael Mann [1986]), nebo stavěli do protikladu západní a východní Evropu (Immanuel Wallerstein [1974], Perry Anderson [1974]). Pojem střední Evropa nepoužívá ani Stein Rokkan ve svých významných studiích ze 70. let, ačkoli jinak věnuje nám analyzovaným státům ve svých studiích dostatečnou pozornost, nebot jsou součástí hlavní oblasti jeho zájmů, totiž „evropských periferií".

V úvodní části stručně zmíníme vznik a vývoj pojmu střední či středovýchodní Evropa. Historická kategorie evropského středu se objevuje na konci 18. století, pravděpodobně nejprve u Johanna Gottfrieda Herdera, pro kterého je střed kontinetu ideálem ležícím mezi asijským despotismem a západním kramářstvím. Po Vídeňském kongresu byl pojem středu Evropy používán Metternichem jako synonymum podunajské monarchie. Postupně o střední Evropě začínali hovořit příznivci německo-rakouského spojení, jako např.

* PhDr. Stanislav Holubec, Ph.D. Imre Kertesz Kolleg, Friedrich Schiller Universität Jena, Leutragraben 1, Jena (SRN) 07743. E-mail: stanislav.holubec@uni-jena.de 
Constantin Franz v 60. letech 19. století, který ji chtěl rozšířit o neruské slovanské národy a vytvořit tak protiváhu Francie a Ruska. V češtině byl pojem zachycen během druhé poloviny 19. století jako zeměpisná kategorie a na počátku 20. století již pojem Central Europe existuje i v angličtině. Svou popularitu jako politický koncept však tato kategorie získala až v práci Friedricha Neumana Mitteleuropa [1915], obhajující svazek Německa a Rakouska a východní expanzi, která měla být ovšem spíše liberálním než militaristickým expansionismem a měla pamatovat na práva malých středoevropských národů. I v meziválečném období existovaly četné diskuse o hospodářském a politickém spojení malých států stř̌ední Evropy, například tzv. Hodžův plán ze 30. let, z tohoto teritoria bývalo naopak tehdy vyčleňováno Německo. Na dosavadní vývoj navázal počátkem 50. let 20. století Oskar Halecki, který použil pojmy středozápadní a středovýchodní Evropa pro Čechy, Polsko a Uhry [bliže viz Hloušek 2003]. Tento region se odlišuje od Evropy východní hlavně katolicismem a od Evropy středozápadní svou multietnicitou, v raném novověku stavovskou společností a nevolnictvím. Daná oblast se stala součástí centralizačních snah tří impérií - rakouského, pruského a ruského, a po rozpadu zmíněných impérií v roce 1918 zde vznikly menší nástupnické státy a region se posléze stal obětí jak nacistické, tak bolševické expanze. Zatímco pojem středozápadní Evropa, používaný Haleckým pro bývalou Svatou říši římskou, se neuchytil, pojem středovýchodní Evropa se prosadil zejména v německy mluvících oblastech a v Polsku. V německém myšlení umožňoval být středem a zároveň nemít za sousedy hned východní Evropu, v Polsku se zase úspěšně uchytil, nebot nabízel možnost do jednoho regionu zahrnovat s Polskem v hranicích z roku 1945 také jeho bývalá, nyní ztracená východní území.

Z autorů druhé poloviny 20. století reflektujících pojem střední nebo středovýchodní Evropa jako prostorové vymezení své analýzy dlužno zmínit alespoň Františka Dvorníka a jeho monografii Zrod střední a východní Evropy [anglicky 1948, česky až 1999], esejistickou práci Jenö Szücse Tři historické regiony Evropy [anglicky 1983, slovensky 2001] a knihu Piotra S. Wandycze Střední Evropa v dějinách [anglicky 1992, česky 1998], jejíž původní anglický název hovoří o středovýchodní Evropě. Tato práce srovnává tisíc let dějin českého, polského a uherského království především z polské a mad’arské perspektivy. V nedávné době se v českém prostředí o podobnou syntézu pro 19. a 20. století pokusil Jan Křen svou publikací Dvě století střední Evropy [2005], přitom Křen do své analýzy vedle Čech, Polska a Mad’arska zahrnuje též Rakousko a Slovinsko. Střední Evropa je mu zřetelně prostorem bývalé podunajské monarchie s pozicí Čech zhruba uprostřed tohoto celku. Pozoruhodným pokusem z poslední doby se stala práce Jaroslava Millera Uzavřená společnost a její nepřátelé: město středovýchodní Evropy (1500-1700) z roku 2006, kde autor tento region ztotožňuje s polským, českým a uherským státem a používá v Čechách málo oblíbený pojem středovýchodní Evropa, ačkoli zároveň zdůrazňuje, že pro něj není „homogením teritoriem, ale spíše shlukem regionů se svébytným politickým, hospodářským, kulturním a sociálním klimatem“ [Miller 2006: 333].

Jak tedy dosvědčují tituly prací zmíněných autorů, region bývá někdy označován jako středovýchodní a někdy střední Evropa. Pojem „středovýchodní Evropa“ přitom nebývá v Čechách příliš používán a převažuje v německém prostředí (Ostmitteleuropa), odkud se dostal i do anglosaského diskurzu (East-Central Europe). V českém diskurzu jednoznačně převažuje pojem střední Evropa, do kterého bývá ovšem někdy zahrnováno též Německo nebo Rakousko. Podle výzkumu veřejného mínění z roku 1996 čeští respondenti zařazovali 
do střední Evropy následující země: ČR $92 \%$, Slovensko $73 \%$, Polsko $72 \%$, Madarsko 71 \%, Rakousko 70 \%, Německo $55 \%$, Švýcarsko 20 \%, Bulharsko 10 \%, Rumunsko10 \%, Francie 9\%, Ukrajina 6\%, Itálie 5\%, Rusko $5 \%$. [viz Kdo... 1996] Pojem „střední Evropa“ je naopak v Německu spjat s imperialistickou koncepcí Friedricha Naumanna z roku 1915 tedy coby prostor, v němž má dominovat právě Německo. Jak ukázali Janowski, Iordachi a Trenscényi, s podobným chápáním pojmu středovýchodní Evropa se setkáme v polských pracích a v tomto kontextu do něj bývají zahrnovány kromě Křenem vyjmenovaných států také Litva, západní Bělorusko a západní Ukrajina. Podle těchto autorů převažuje v madarském, stejně tak jako českém prostředí pojem střední Evropa, ale na druhou stranu zde panuje tendence zařazovat do této kategorie Sedmihradsko, Vojvodinu či Chorvatsko [Janowski, Iordachi, Trenscényi 2005]. Obecně tak platí bonmot T. G. Ashe „řekni mi svou definici střední Evropy a já ti řeknu, odkud jsi“ [cit. dle Trávníček 2009: 7]. Přehledné a analytické použití tohoto pojmu tedy v konečném důsledku problematizují nejasné hranice jím stanoveného regionu. Používat pojmy „střední nebo „středovýchodní Evropa“ pro stř̌edověk nebo raný novověk je ale ještě problematiččjǰ̌í, a to $z$ důvodu, že tehdy tyto pojmy ještě vůbec neexistovaly. Vzhledem k celkové nejednoznačnosti tohoto termínu hovořím proto na následujících stránkách raději o společných vývojových tendencích či odlišnostech v rámci českého, uherského a polského státu.

Stalo se zřejmou skutečností, že diskuse o centrech a periferiích, respektive o nerovnoměrném rozvoji v dějinách střední Evropy jsou dnes poněkud zapomenuty pod vlivem postmoderny a kulturalistického obratu, ačkoli v 80 . letech byly velmi živé díky výskytu celé řady historicko-sociologických prací s ambicí nastolit nové vyprávění o minulosti nadstátních územních celků. Stř̌ední Evropa tehdy byla zároveň široce diskutována v disidentských kruzích jako společné dědictví států utlačovaných sovětskou mocí, o které je možné se opřít v pokusu o vymanění se z vlivu Moskvy. Poté, konkrétně v 90. letech diskuse ustaly a ze střední Evropy se stal $v$ nejlepším př́padě předmět dějin diskurzů nebo dějin pojmů (viz výše zmíněná studie Janowskiho a kol.). Teprve tendence posledních let svědčící snad o jisté obnově zájmu o historickou sociologii především $\mathrm{v}$ českém prostředí společně s objevováním krizových jevů společných všem postkomunistickým zemím a provázených v zahraničí zájmem o global history nebo dějiny transnacionálního rozšiřování různých kulturních a společenských fenoménů nás vedou $\mathrm{k}$ domněnce, že by snad bylo vhodné pokusit se tuto diskusi o společných osudech našeho regionu oživit. Pokud by se tedy této studii podařilo změnit se $\mathrm{v}$ takovouto výzvu, mohli bychom považovat její cíl za více než naplněný.

\section{Společné vývojové tendence}

Z hlediska celoevropského srovnávání posuzuje společně Polsko, Čechy a Uhry Stein Rokkan. Tento norský autor přitom pokládá za určující pro vývoj českého, polského a uherského státu ve středověku a raném novověku hned několik faktorů, mezi nimiž první místo zaujímá geografie. Všechny tři země totiž přiřazuje k vnitrozemské zóně Evropy vzdálené od námořních cest. Druhý faktor podle něj představuje tradice římské státnosti. Český a polský stát leží mimo hranice bývalé Římské říše, zatímco uherský stát na jejích hranicích, ovšem populační změny zde byly tak hluboké, že zde nebylo možné na rozdíl od jiných území rímské rríše udržet jakoukoliv kontinuitu. Třetí faktor tvoří blízkost k evropskému 
„městskému pásu“ existujícímu od 12. století mezi severní Itálií a Nizozemím, již proto Rokkan správně nachází malou v Polsku a Uhrách a větší v Čechách. Především však podle Rokkannových závěrů spočívají mnohé problémy těchto států ve skutečnosti, že základním dějinným východiskem příslušných území je jejich periferní postavení, tedy že představují území trpící nedostatkem lidských, ekonomických, vojenských a kulturních zdrojů a že ve vnitrozemí kontinentu bylo navíc velmi obtížné zformovat silnou velmoc, nebot by byla stále ohrožena expanzí z okrajů [cit. dle Hloušek, Kopeček 2004: 16-23].

Během nejrůznějších diskuzí historiků a sociologů v 80. a 90. letech o procesu modernizace i problematice světového systému bylo nejčastěji zmiňováno několik základních společných vývojových tendencí či rysů zkoumaného regionu od raného středověku, které se pokusím v následujícím textu přiblížit.

První společnou vývojovou tendencí, jak ji dobře známe z literatury, je společná christianizace regionu během 9.-10. století západní variantou křestanství, přičemž samotná christianizace byla oproti západu a jihu Evropy opožděná, takže christianizací zde nevznikají státy vedené domácí aristokracií. Region tedy nesdílel osud Polabských Slovanů nebo obyvatel Pobaltí, kde vznikly státní struktury jako nástroje německých kolonizátorů, z kolonizátorů se následně utvořila vládnoucí vrstva a christianizace zde byla spojena s germanizací místního obyvatelstva. Region však nesdílel ani osud Balkánu nebo východní Evropy christianizované z Byzantské ř́rše. Byzantská misie se sice pokoušela sem proniknout, jak vidíme na př́kladu Velké Moravy nebo byzantského vlivu v počátcích uherského státu, blízkost center západního křestanství ale nedávala této misii naději na úspěch. Pouze Uhry mohly pomocí hrozby byzantskou kartou získat ve svých počátcích od Ríma značná privilegia. Z hlediska časového vzniku všech tří států patří ustavení Polska a Uher do doby poněkud pozdější než vznik západněji ležícího českého knížectví: pokud vezmeme za symbolické datum vzniku státu pokřtění zdejších panovníků, spadá tento okamžik v českém případě již do roku 872, zatímco v prrípadě polského Měška do roku 966 a uherského Gejzy až do 70. let 10. století.

Proces utváření nezávislých států proběhl nejúspěšněji počátkem 11 . století v Uhrách a Polsku, zatímco suverenita českého státu byla v raném středověku jen částečná, nebot byl donucen již v 10. století vstoupit do svazku s německou říśí, která také v českých zemích po následující dvě století velmi aktivně mocensky zasahovala. Ačkoli se za prvních Přemyslovců, zejména Boleslava I., zdálo, že bude český stát vyrovnaným partnerem poněkud později se formujícího Mad’arska a Polska, jeho hluboká krize z počátku 10. století, způsobená nástupem těchto dvou velmocí stejně jako tlakem z německé říše, jej na další dvě století odsunula v rámci regionu do druhořadé pozice. Mad’arsko a Polsko získaly královský titul v letech 1000, respektive 1025, ačkoli pouze v Uhrách přetrvala královská tradice bez přerušení také v 11. a 12. století, zatímco Čechy získaly korunu v dědičné formě až v roce 1212. (V Polsku byl dědičný královský úřad obnoven na konci 13. století.) Polsko a Uhry byly sídlem arcibiskupství v roce 1000, zatímco české země až v roce 1344. České země byly součástí Svaté říše římské, zatímco Polsko a Madarsko byly daleko volněji podřízeny přímo papežskému stolci. Na druhé straně měly české země nezávislejší postavení než většina ostatních říšských území. Na rozdíl od většiny území německé říše totiž na českém území neležela říšská léna, takže nebyl zpochybňován nárok přemyslovské dynastie na zdejší vládu a německý císař nekonal po českém území své inspekční cesty a pouze potvrzoval nové panovníky v úřadu. 
Př́ičiny slabšího mezinárodního postavení českého státu lze spatřovat v méně příznivé geopolitické situaci. Polsko a Mad’arsko dokázaly zřetelně využít relativní odlehlosti od gravitačního centra středověké německé říše a zároveň mohly rozvinout snadnou expanzi východním směrem. Východní expanze se dařila českému státu pouze za Boleslava I., kdy úspěšně pronikal do Haliče mezi zájmy dosud nepř́liš silného Polska a Madarska. Objevení se nových mocností na jihu a severu Boleslavovy domény, stejně tak jako ona první raně středověká krize a stagnace českého státu v 11. a 12. století jakoukoli východní expanzi znemožňovala. Menší geografický rozsah českých zemí a zároveň ztížená možnost územní expanze naopak vedly k tomu, že se panovnická moc během 11. a 12. století územní expanzí nevyčerpávala a mohla vytvořit dostatečně centralizovaný a efektivní středověký stát menšího rozsahu.

K raně středověké krizi došlo nejen v českém státě, ale i v Polsku po roce 1025, kde se podobně jako český stát Boleslava I. polský stát Boleslava I. Chrabrého rozpadl krátce po jeho smrti. Na rozdíl od státu českého, který se konsolidoval za Oldřicha a Břetislava jako území v územním rozsahu zhruba dnešní ČR a v této velikosti setrval až do poloviny 13. století, se polský stát podařilo za Kazimíra I. obnovit téměř ve velikosti z doby Boleslava I., nicméně pouze jako velmi volný svazek jednotlivých knížecích údělů, jenž dokonce rezignoval na královskou korunu. Úpadek významu země je patrný na skutečnosti, že císař Friedrich Barbarossa po synodě v Pavii roku 1160 vyslal poselstva s jejími výsledky ke španělskému, anglickému, francouzskému, dánskému, českému a uherskému králi, ale nikoli k panovníku polskému [Bartlett 2009: 22]. Zmínění Čech mezi předními evropskými monarchiemi je však možno přičíst spíš jejich začlenění do Německé ř́iše, než případnému celoevropskému významu. Německý císař Barbarossa měl zkrátka zájem na tom, aby byl jeho první spojenec v říši dobře informován. Nepřítomnost blízkých mocenských center ovšem na rozdíl od státu českého nevytvářela nebezpečí trvalého podrobení polských území jednomu z těchto mocenských center. Polská státnost tak přežívala i přes rozdrobenost země a jistou centralizaci polského státu se podařilo obnovit až počátkem 14. století. Naopak Mad’arsko tuto raně středověkou krizi po smrti úspěšného zakladatele Štěpána I. (997-1038) prakticky nepoznalo a země si zachovala svou relativní centralizaci. Důvodem byla patrně odlišná sociální struktura třídy mad’arských feudálů, kteří od počátku pocházeli z vojenské aristokracie kočovného kmene Mad’arủ, a byli tak daleko silněji spjati s panovníkem, na rozdíl od Polska, kde zdejší feudální struktura více odpovídala starým místním vladyckým rodům, a vytvářela tak větší nebezpečí rozdrobenosti. Svou roli možná sehrál i stepní charakter uherské nížiny, umožňující rychlé přesuny uherského jezdectva, čímž bylo zabráněno odstředivým tendencím. Územní expanze Uher pokračovala rovněž na konci 11. století za Štěpánova nástupce Ladislava, který pro svou zemi vybojoval hranice existující (s výjimkou osmanské invaze) až do roku 1918. Nicméně ani Uhrám a Čechám se nevyhnulo postupné posilování mocenských pozic šlechty a oslabování centrální moci ve 13. století. Krize uherského středověkého státu se dostavila teprve ve 13. století s invazí Mongolů, která zpustošila zemi v podobném rozsahu, jakou představovala pro západní Evropu morová nákaza v polovině 14. století. Také tuto krizi se ale podařilo Uhrám poměrně rychle překonat a země se mohla začlenit do zlatého věku středoevropských monarchií ve 14 . století (někdy se v této souvislosti hovoří o tzv. druhém založení Uher). Jak uvádí Davis, mongolská invaze naopak napomohla expanzi polského státu, nebot’ oslabila Kyjevskou Rus natolik, že sem mohlo Polsko ve 14. století 
snadno expandovat [Davis 2003: 269]. Polské Slezsko bylo nicméně mongolskou invazí poničeno taktéž.

Druhým společným rysem, respektive procesem doprovázejícím v celém regionu christianizaci byla německá kolonizace. Ta probíhala na rozdíl od christianizace pomaleji a pochopitelně v menším geografickém rozsahu. Německá kolonizace a germanizace místního obyvatelstva se přitom objevuje ve dvou formách: v blízkosti německého území docházelo k posouvání jazykové hranice a v odlehlejších územích k vytváření německých jazykových ostrovů (především v Mad’arsku, Rumunsku a na Slovensku). Germanizace nejúspěšněji probíhala podél hlavních komunikačních cest, tedy Podunajím, kde se během 11. století setkalo německé a mad’arské osídlení u Vídně, tj. mezi Labem a Odrou, a také do Slezska, kde německé osídlení dorazilo během 14. století až k Opoli, a konečně podél Baltického moře, kde německé osídlení dosáhlo v téže době Královce. Příčinou německé kolonizace bylo relativní přelidnění v původní vlasti a zároveň možnost sociálního vzestupu v novém domově, nebot půda na východě byla považována za velmi úrodnou. Jak napsal brémský biskup: „Slované jsou sice odporní lidé, ale jejich zem je bohatá na med, obilí i ptactvo, že jí není rovné. Jděte na východ. Tam spasíte svou duši a zároveň získáte nejlepší půdu k životu“ [cit. dle Cipolla 1994: 185]. Obzvláště dynamickým obdobím německé kolonizace se stalo 13. století, během nějž se začala významněji projevovat zakládáním měst, poté se však posouvání jazykové hranice zpomalilo. Dvě území byla navíc vưči německé expanzi rezistentní, patrně pro svou obtížnější přístupnost a menší zajímavost, protože ležela mimo hlavní obchodní cesty: české země a odlehlé centrální Polsko mezi Vartou a Vislou. Právě české západní hranice jsou případem nejpomalejšího posunu jazykové hranice, která se zde posunula mezi léty 700 , odkdy se datuje počátek germánské kolonizace, do roku 1400, kdy byla v zásadě ukončena, jen o několik desítek kilometrů. Německá kolonizace nemá co se jejího rozsahu i kulturního významu týče srovnání s kolonizací jiných etnik ve zkoumaném regionu - Poláků na východ nebo Mad’arů v rámci velkých Uher či Řeků na Balkáně.

Jak již bylo řečeno, německá kolonizace znamenala zakládání vesnic i měst. Během 13. a 14. století se tak v námi zkoumaném regionu utvořila relativně hustá městská sít, která byla ovšem značně heterogenní co do hustoty a velikosti sídel. Tak třeba tehdejší česká města by bylo možné přirovnat $\mathrm{k}$ městům saským a bavorským, zatímco městská sít Polska směrem na východ nebo v okrajových oblastech Uher byla zakládána poněkud později, ve východních oblastech zkoumaného regionu ztrácela na hustotě a přecházela $\mathrm{v}$ řídce osídlenou a pastevecko-zemědělskou krajinu. Kolem roku 1400 bylo v Uhrách jen dvacet hrazených královských měst [Kontler 2001: 92], v Čechách a na Moravě jich byly v té době čtyři desítky a dalších devadesát opevněných měst a městeček patřilo šlechtě. Svou hustotou a velikostí ale v 14. a 15. století překonávala česká, polská i uherská sít měst urbanizaci britských ostrovů (s výjimkou jihu) či Švédska a Norska [Andrén 1994], o Balkánu nebo oblastech Ruska nemluvě. Na rozdíl od německých, italských a francouzských oblastí byla ale města našeho regionu malá a nepředstavovala přirozená centra rurálních oblastí, takže zde nemohly vzniknout politicky významné městské svazy [Klusáková 1996: 117-119, cit. dle Hloušek, Kopeček 2004: 16-23]. Ve srovnání s mnoha zeměmi jižní a západní Evropy rovněž v našem regionu neexistoval protiklad mezi vyspělými pobřežními městy a méně rozvinutými vnitrozemskými oblastmi. Podle Jaroslava Millera dokonce „teorie o městech jako ostrůvcích kapitalismu ve feudálním moři byla v prostoru středovýchodní Evropy 
v ještě zjevnějším rozporu s dobovou realitou než v kontextu Evropy západni““ [Miller 2006: 327]. Středoevropská města pro něj tedy nepředstavují ostrůvky modernity, nýbrž právě naopak brzdu změn. Podle řady autorů pak bylo omezování moci měštanstva panovníkem a šlechtou a úpadek měst v regionu v 16. a 17. století předzvěstí úpadku celé oblasti.

Třetím společným rysem regionu je oproti západní Evropě opožděný vrcholně středověký vzestup ve 14. století, který se stal obzvláště viditelný díky tomu, že region byl relativně ušetřen morové nákazy v polovině 14. století, jež zdecimovala západoevropské obyvatelstvo. ${ }^{1}$ Dynamický rozvoj regionu ale můžeme nacházet již ve 13. století, kdy dochází k masovému zakládání měst v Čechách a na Moravě, ve Slezsku, v západních Uhrách a na Slovensku, podobně jako v Malopolsku a v okolí Gdaňsku. Ve 14. století nacházíme jak v Polsku, tak v Uhrách a v českých zemích (ve 14. století) př́íklady slavných panovníků, pod jejichž vládou se země kulturně i ekonomicky rychle rozvíjely a zároveň zvětšovaly svůj územní rozsah. Polský stát Kazimíra Velikého (vládl 1333-1370) prováděl úspěšnou územní expanzi východním a severním směrem a na svém vrcholu dosáhl okolo 2,5 milionu obyvatel. Též český Karel IV. (1346-1378) zvětšil své území severním a západním směrem a jeho državy mohly mít 5 milionů obyvatel (Čechy, Morava, Slezsko, Lužice, Braniborsko, Horní Falc). Uherský Ludvík Veliký (1342-1382) rozšíríl svou sféru vlivu do Dalmácie a na Balkán a počet obyvatel Uher mohl za jeho vlády dosáhnout 3 milionů. ${ }^{2}$ Podobně jako Karel IV. založil Ludvík Veliký první mad’arskou univerzitu v Pécsi (1367) a Kazimír Veliký univerzitu v Krakově (1364), takže se někdy ve vztahu k tomuto regionu hovoří o druhé vlně zakládání středověkých univerzit. Ludvíku Velikému se dokonce podobně jako českému Václavu II. podařilo v letech 1370-1382 sjednotit pod svou vládou Polsko a Uhry. Opakované neúspěšné pokusy toto území sjednotit přitom ukazují na jeho velkou heterogenitu a zároveň na slabost jednotlivých zemí, které ani na vrcholu své moci nebyly schopné stát se trvalým centrem regionu. I přes tuto vrcholně středověkou konjunkturu zůstala většina našeho regionu ve skupině méně rozvinutých oblastí Evropy, jak argumentuje např. Nolte [1993]. Velmi dobrým důkazem tohoto stavu jsou počty biskupství, kardinálů a kanonizovaných světců ve srovnání se západem Evropy. Přestože zde mohlo ve druhé polovině 14 . století žít asi $15 \%$ populace západního křestanstva, nacházelo se zde jenom 7,2\% biskupství a region měl bud' slabé, nebo vůbec žádné zastoupení mezi kardinály a ani jeden světec kanonizovaný papežem v letech 1305-1431 nepocházel z této části Evropy [Šmahel 1995: 75-76]. Nolte pro to samé období uvádí, že za stejně velký pozemek musely biskupství Francie a Itálie platit papežské kurii 1000 zlatých, kurie španělské, východoněmecké či české 100-199 zlatých a madarské či polské méně než 100 zlatých, což ukazuje, jak si byla kurie vědoma, že stejně velká území mají v různých zemích různé výnosy [Nolte 1997: 40].

1 Zaostalost regionu vůči západu a jihu středověké Evropy ovšem nic neříká o životní úrovni dolní většiny obyvatel v raném a vrcholném středověku. Ta mohla být podle Kontlera dokonce vyšší než v západní Evropě, nebot' země s malou hustotou obyvatel netrpěly tak často hladomorem jako hustě osídlená území. V méně hustě osídlených oblastech také bylo možné se výrazněji orientovat na chov dobytka a rybolov, což byla odvětví ne tolik závislá na rozmarech počasí jako obdělávání půdy, a tím se snižovalo riziko hladomoru [Kontler 2001: 58].

2 Počet obyvatel nehrál ovšem ve středověku příliš velkou roli v prrípadě, že šlo o populaci obývající velmi řídce osídlené území. Základem moci středověkých panovníků byla spíše velká města generující bohatství, doly na drahé kovy nebo území, z něhož šlo efektivně mobilizovat vojenskou zemskou hotovost. Z tohoto důvodu se středověké státy ani nepokoušely o odhad počtu vlastních obyvatel, natož o nějakou formu sčítání lidu. 
Na rozdíl od českých zemí nenastala v Polsku ani Mad’arsku podobná společenská krize podobná posledním letům vlády Václava IV., ústících do husitských válek, které prohloubily existující ekonomické i kulturní zpoždění českých zemí za západem Evropy o několik dalších desetiletí (ačkoli zároveň představovala česká reformace významný příspěvek evropské kultuře). Společenský úpadek v Uhrách nastal v mírné podobě po smrti Matyáše Korvína a naplno propuká teprve v souvislosti s osmanskou expanzí po roce 1526. V Polsku pak dochází k úpadku až na konci 16. století, přičemž diskuse historiků ukazují na celou řadu příčin tehdejšího polského úpadku. Okolnosti a zdroje společenské krize 15. století v Čechách byly obzvláště v minulosti předmětem širokých diskusí historiků a obvykle v nich bylo poukazováno na specifika společenské struktury českého království tak, jak byla ustavena během 14. století. Toto sociální rozvrstvení v sobě obsahovalo značný krizový potenciál, nebot se vyznačovalo příliš rozsáhlým církevním majetkem, přespříliš početnou nižši šlechtou a řadovým kněžstvem nacházejícím obtížně své uplatnění, nehledě na zhoršující se podmínky tzv. městské chudiny. František Šmahel mluví v této souvislosti o prŕliš rychlém vyrovnávání úrovně rozvoje českých zemí se západem Evropy, „přičemž dynamika tohoto procesu však nejednou překonávala míru únosnosti, zvláště když některé vnější podněty (schizma, změny na římském stolci apod.) přinášely na pořad dne nové problémy“ [Šmahel 1995: 157]. Celému procesu podle něj dodával další dynamiku multietnický (česko-německý) charakter českých měst spojený s dominancí německého měštanstva a aspiracemi nižšího měšţanstva českého. Z husitských válek vyšla jako vítěz nižší i vyšší šlechta a jejich poraženými se staly církev a královská koruna. České země se začaly více podobat Polsku a Uhrám, nebot došlo k vytvoření stavovského státu se slabou panovnickou mocí.

Polsko se na rozdíl od českých zemí úspěšně rozvíjelo i po smrti Kazimíra Velikého. Polsko-litevská unie, která z něj učinila stát největšího územního rozsahu v katolické Evropě, byla ustavena roku 1385. Země dosahovala i po celé 15. století dalších územních zisků na úkor řádu Německých rytírů a Zlaté Hordy a Krakovská univerzita převzala mnohé z mezinárodního věhlasu Univerzity Karlovy, která kvůli husitským válkám upadla do bezvýznamnosti. V 15. století zde studovaly tisíce zahraničních studentů [Samsonowicz 1997: 114] a Polsko zažívalo až do počátku 17. století intenzivní populační růst, zatímco v Čechách došlo v souvislosti s husitskými válkami k populačnímu poklesu stejně jako v Uhrách od roku 1526, v tomto př́padě v souvislosti s osmanskou invazí. Také Uhry prožívaly v 15. století kulturní a hospodářský vzestup, který kulminoval zvláště za Matyáše Korvína (1458-1490). Tento panovník chtěl kromě českého královského titulu získat též rímský trůn a za tímto účelem přesídlil roku 1485 do Vídně, odkud vyhnal římského císaře Friedricha, ale zemřel zde dřív, konkrétně v roce 1490, než se mu tento plán povedlo uskutečnit. Pokus Matyáše Korvína vytvořit středoevropskou monarchii se sídlem ve Vídni tak pouze předznamenal budoucí úsilí Habsburků.

Z hlediska vývoje hospodářství je zřejmé, že ačkoli se Uhry a Polsko vyhnuly českému kolapsu v 15. století, jejich hospodářská úroveň nikdy nedosáhla úrovně české. Třebaže existovaly v Uhrách i v Polsku oblasti s výraznou mírou hospodářského rozvoje a velkou hustotou obyvatel (západní Uhry, Němci osídlená území Slovenska a Sedmihradska, Malopolsko, pobřeží Baltického moře), nemohly se tyto srovnávat s českými zeměmi, které, ačkoliv ležely daleko od mořského pobřeží, kde se především odehrával hospodářský život středověku, profitovaly z velkých zásob stř́ibra a $\mathrm{z}$ blízkosti hustě osídleného území 
Německa. Zvláště se to týkalo oné středověké protokapitalistické enklávy mezi Augšpurkem a Norimberkem [Křnen 2005: 51], která za sebou do značné míry táhla okolní regiony. Bohatství drahých kovi̊ nebylo ale jen českým specifikem, podle Kontlera zaujaly Uhry ve 14. století pozici největšího producenta zlata v Evropě [Kontler 2001: 76]. Praha byla od 13. do 16. století největším městem regionu, jemuž mohl v 15 . století v souvislosti se vzestupem baltického obchodu konkurovat pouze Gdaňsk, který měl okolo roku 1450 30 tisíc [Adamczyk 2001: 112] a na konci 16. století již 50 tisíc obyvatel [Kochanowicz 1989: 111]. Naproti tomu např́iklad Krakov ani Budín se Praze nemohly svou velikostí rovnat. Na druhou stranu byly ovšem Čechy a Morava ve vrcholném středověku poněkud zaostalejší, nežli poblíž ležící Bavorsko, Sasko i Slezsko, jak nám napoví srovnání velikosti městských center nebo kvality umělecké produkce. Taktéž sít měst byla v Čechách rozvinutější než v Uhrách a Polsku, byt’ zase zaostávala za městy německými.

Čtvrtým společným rysem regionu bylo prosazování reformace v 15. století, a naopak nástup katolické protireformace ve století sedmnáctém, která v tomto regionu nakonec převážila. Čechy a Morava představují v tomto bodu nejradikálnější případ: reformace se zde uplatnila jako první a také získala většinu společnosti na svou stranu, během 16. století ale ztratila svou dynamiku a stala se obětí centralizace katolické absolutistické monarchie. České a moravské obyvatelstvo bylo na rozdíl od Polska a Uher po roce 1621 zcela přinuceno konvertovat ke katolictví. ${ }^{3} \mathrm{~V}$ Uhrách uspěla reformace rovněž ve velkém rozsahu, ovšem později a v importované podobě, především ke kalvínství se v 16. století hlásilo až $80 \%$ obyvatel země [Kontler 2001: 136]. Mimořádnému nástupu reformace v Uhrách patrně napomohl i kolaps katolického státu pod osmanským tlakem, a pokud jde o Polsko, reformace se uplatnila jen v malém rozsahu. V obou zemích se protestantství (luteránství a kalvinismus) šířilo především díky početným německým menšinám ve městech, které ji přejímaly ze západu. Podobně jako v Čechách po Bílé hoře se také v Mad’arsku prosazovala habsburská protireformace, ale nebyla zde zdaleka tak úspěšná. Habsburský stát nebyl totiž v 17. století schopen simultánně bojovat proti Turkům a uherským protestantům, a zároveň protestanti soustředění především v odlehlém Sedmihradsku neohrožovali přímo jeho existenci, na rozdíl od pro vídeňské Habsburky strategicky významných českých zemí. Třetina mad’arského etnika tak zůstala protestantská až do 20. století. Polsko se vyznačovalo v 15.-16. století náboženskou svobodou patrně danou skutečností, že protestantství zde zůstalo relativně malou menšinou podobně jako další náboženské kulty - židovství, pravoslaví, uniatství (vzniklé v roce 1596), a dokonce islám a přitom však chyběly dostatečně silné státní orgány schopné prosadit náboženskou centralizaci společně s centralizací politickou. $\mathrm{Z}$ tohoto důvodu dochází i k významné emigraci židovské populace do Polska v 16. století a území Polska a západní Ukrajiny se tak stala do 20. století regiony s nejvyšším podílem Židů na počet obyvatel v Evropě. Teprve války proti protestantskému Švédsku a pravoslavnému Rusku během 17. století posílily katolickou orientaci této země [Křen 2005: 52], v roce 1772 se přesto podíl katolíků v polském státu odhadoval jen okolo $43 \%$.

\footnotetext{
Selhání české reformace vysvětluje Perry Anderson v návaznosti na starší české historiky skutečností, že česká protestantská šlechta nedokázala vytvořit s širokými českými vrstvami svazek, který by byl účinnou silou proti habsburskému expanzionismu. Naopak v Nizozemí byly tamní stavy podobného kroku schopné a země se dokázala v analogické situaci silnějšímu katolicko-habsburskému agresorovi ubránit. Přesto Anderson nazývá české stavovské povstání „největší krizí, v jaké se Habsburská monarchie ocitla“ [Anderson 1979: 306] a následnou rekatolizaci označuje za „nesrovnatelnou s čímkoli na celém kontinentu“ [Anderson 1979: 309].
} 
Pátým společným rysem je zesílená integrace regionu do světové ekonomiky ve století šestnáctém a s ním, alespoň podle Wallersteina a dalších autorů vycházejících z perspektivy teorie závislosti a teorie světového systému, spojený úpadek, ačkoli jiní autoři dávají tento úpadek do souvislosti hlavně s objevením se nových absolutistických a na expanzi orientovaných zemí, zatímco země regionu nebyly schopny ustavit podobnou strukturu společenského uspořádání. V Polsku bylo, jak známo, hlavním integračním artiklem do evropské ekonomiky produkce obilí. Zájem o ně vzrostl na Západě spolu s pokračujícím demografickým růstem a dále reorientací jihoanglické a nizozemské ekonomiky směrem od zemědělské výroby k produkci vlny pro manufakturní výrobu sukna, takže obyvatelstvo těchto regionů již nedokázala uživit vlastní zemědělská produkce. Třetím faktorem se stal nástup nových typů lodí, které umožňovaly od 15. století přepravu většího množství nákladu. Z Polska ovšem nebylo vyváženo jenom obilí, ale i dřevo, jehož západoevropská cena stoupla během 15 . století čtyřicetkrát, nebot’ v této době došlo k radikálnímu úbytku lesů vykácením [Kochanowicz 1989: 95]. Jak působivě, nicméně nikoli bezproblémově argumentoval Marian Malowist [1954] a po něm Immanuel Wallerstein [Wallerstein 1974], zapojením Polska do mezinárodního obchodu nastává celý řetězec událostí vedoucí k hospodářskému úpadku země, nebot’ za zisky z prodeje obilí si polská šlechta nakupovala západní luxusní zboží, jehož domácí produkce proto upadala, a zároveň, aby polská šlechta zvýšila své zisky, snažila se zvýšit míru vykořistování poddaných (tzv. druhé nevolnictví) a mocensky potlačit města. Tak se podle těchto autorů dává do pohybu proces, na jehož konci se Polsko stalo zemědělskou zásobárnou měst západní Evropy a polská šlechta nejmocnější silou v zemi, zatímco centra modernizace - města a zárodky centralizované raně moderní monarchie - byla potlačena. ${ }^{4} \mathrm{~V}$ Mad’arsku hrál roli polského obilí dobytek, po jehož mase vzrostla tehdy poptávka na Západě podobně jako po polském obilí. Země se stala hlavním evropským vývozcem skotu a rychle rozšiřovala pastviny, což bylo umožněno relativně řídkým osídlením a blízkostí západní Evropy, kam vedla Podunajím relativní rychlá cesta. Uherský dobytek tudy byl každoročně v početných stádech hnán na Západ a byl hlavním vývozním artiklem Madarska až do 18. století, druhým nejvýznamnějším vývozním artiklem z Uher pak bylo víno.

České země byly kvưli své relativní odlehlosti od moře a velkých ř́ičních toků zapojeny do mezinárodního obchodu 16. století méně než Polsko a relativní nedostatek půdy z nich mohl jen obtížně učinit producenta dobytka. Nárůst mezinárodního obchodu zde proto nebyl, srovnáme-li 14. a 16. století, tolik patrný jako v př́padě Polska či Uher. Přesto rovněž zde nacházíme vzorec, v jehož rámci byly české země vývozcem zboží s menší přidanou hodnotou (především drahých kovů) pro jižní Německo, a naopak dovážely zboží s vyšší přidanou hodnotou [Maur, Horská, Musil 2002: 72-74]. Pokud jde o těžbu stř́ibra, bylo by možné jí připsat poněkud omezený vliv na lokální blahobyt, nebot’ mnoho z jeho hodnoty odplynulo do ciziny, aniž by nějak přispělo k rozvoji země. Šlechtické podnikání v Čechách

\footnotetext{
4 Vzniká otázka, do jaké míry bylo raně novověké zaostávání regionu pouze pokračováním starších historických tradic sahajících až do dob Rímské říše, která se s výjimkou západu Mad’arska do této oblasti nerozšírila, a do jaké míry se region skutečně hospodářsky propadl oproti západní Evropě během 16. a 17. století. Mějme na paměti, že novověk učinil oproti středověku rychlejším i kulturní transfer, a tedy rovněž případné dohánění. Zatímco mezi prvním použitím gotiky a jejím uplatněním v českých zemích uplynulo 80 let, čas mezi vznikem barokního slohu v Itálii a prvními barokními stavbami u nás se počítá na dvě či tři dekády. Tato skutečnost spíše zpochybňuje tezi o prohlubujícím se zaostávání v 16. a 17. století.
} 
16. století dosahovalo zvyšování zisku spíše než znevolňováním rolníků, které se masověji objevuje až po Bílé Hoře, výstavbou rybníků nebo pivovarnickou produkcí a povinným odběrem ryb a piva poddanými. Ačkoli i česká města zažila v 17. století podobný úpadek jako města mad’arská a polská, od konce 18. století se opět rozvíjela v souvislosti s expanzí plátenictví, železářství a sklářství, což bylo opět umožněno blízkostí rozvinutého německého a rakouského trhu a zároveň $\mathrm{v}$ případě sklářství velkými zásobami dřeva v horských oblastech. Český propad proto nebyl tak hluboký jako hospodářský úpadek Polska a Uher a relativní prosperita 18. století připravila dobrou výchozí pozici pro industrializaci druhé poloviny 19. století.

V polském případě novější výzkumy ukázaly, že na rozdíl od dřívějších představ Malowista a Wallersteina neměla integrace Polska do světové ekonomiky okamžité negativní následky. Oproti staršímu bádání dokonce není možné vinit $\mathrm{z}$ úpadku země ani výlučně „nenasytnou a marnotratnou šlechtu“. Na polské šlechtice té doby tedy nelze pohlížet jen jako na peněz a válčení chtivé jedince, kteří hlavně hleděli vytěžit z poddaných obilí za co nejnižší náklady. Zejména mnozí protestantští šlechtici se pokoušeli o produktivnější způsoby podnikání, ${ }^{5}$ většina šlechtických podnikatelů ovšem dosahovala zisku především dalším znevolňováním sedláků a investice do technologií považovala za neúčelné.

Podle Samsonowicze a na rozdíl od Wallersteinovy koncepce neměla devastující dopad „periferní role Polska jako producenta obilí v mezinárodním obchodu“, ale právě naopak úpadek této role. Samsonowicz v těchto souvislostech argumentuje, že 16. a počátek 17. století, kdy toto zapojení vrcholí, znamenalo přece zlatý věk Polska. Mezinárodní obchod s obilím se od 18. století přesunul do Ruska (a také do vnitrozemí Anglie a Francie, zejména díky budování říčních cest v těchto zemích), obchod se dřevem zase do Norska, a to díky lepším konstrukcím lodí. Před prvním dělením Polska činil mezinárodní obchod s obilím jen třetinu množství, kterého dosahoval na svém vrcholu ve druhém desetiletí 17. století [Samsonowicz 1997: 133]. Úpadek obchodu se dřevem a obilím vedl ke zchudnutí polské aristokracie a ke snížení její vojenské moci. Další podíl viny přisuzuje Samsonowicz útokům mocných sousedů, na Polsko totiž útočilo na konci 17. století Švédsko, posílené ve třicetileté válce, Moskevská Rus, Osmanská říše, v 18. století se pak přidalo i Prusko a Rakousko. Podle Kochanowicze se tudíž zdá, že v širším významu byly příčinou dělení slabost polského státu a zároveň vzestup silných států v sousedství [Kochanowicz 1989: 115]. Navíc Polsko v 18. století disponovalo armádou nejmenšího rozsahu v celé středovýchodní Evropě. V Prusku činil počet vojáků $3 \%$ celé populace, v Polsku pouhá $0,2 \%$ a teprve reformou v roce 1788 byl počet vojáků zvýšen na jedno procento obyvatel, ale to už bylo pozdě. Zatímco v 16. století se polské armádě tvořené šlechtou početnější než v jiných zemích nemohlo téměř nic vyrovnat, od vzniku absolutistických států dochází k vytvoření masových standardizovaných armád, kterým nemohla být polská zemská hotovost konkurentem. Tak se stalo vítězství před Vídní roku 1683 posledním okamžikem polské válečné slávy na několik dalších stovek let [Samsonowicz 1997: 136]. Podobně mělo Polsko také jednu z nejnižších měr zdanění v Evropě, což podrývalo sílu polského státu. Tak například americký historik Robert Roswell Plamer odhadl, že výše daní byla v roce

\footnotetext{
5 Např. Mikolaj Rej (1505-1569) začínal jako zeman se dvěma vesnicemi a na konci života se jeho panství rozrostlo na sedmdesát obcí a dvě městečka. Zakládal rybníky a pivovary, osídloval pustá místa sedláky, peníze si půjčoval jen na investice, nikoli na luxusní život, a své dluhy vždy splatil [Kochanowicz 1989: 105].
} 
17751 šilink v Polsku, 6 šilinků v Prusku a Rusku a 21 šilinků v Rakousku [Kochanowicz 1989: 115].

V mad’arském případě bývá hospodářský úpadek připisován válečným operacím spojeným s osmanským dobýváním země a jejím habsburským znovudobýváním, v českém případě s událostmi třicetileté války. Vojenská porážka Uher měla ale hlubší kořeny než pouze obrovskou moc osmanské říše. Turci nevkročili do kvetoucí říše, nýbrž do země oslabené boji mezi jednotlivými stavy, rolnickými povstáními a stagnací ekonomiky, která vedla k nárůstu moci šlechty a úpadku měst [Kontler 2001: 119, 122]. Osmanská okupace Uher navíc nebyla pro zemi zdaleka takovou katastrofou, jak by se dalo očekávat. Do Uher přicházeli od 14. století imigranti nejenom z Balkánu, ale také uprchlíci z Anatolie, kteří utíkali před Turky, a migrace z jihu pokračovala i za osmanské okupace. Turky okupované Uhry nebyly odříznuty od Evropy ekonomicky, a mohly se tak stát největší evropskou zásobárnou masa a vína [Kontler 2001: 143-144]. Až teprve nová vlna válek během 17. století znamenala skutečné dílo zkázy. Když habsburská vojska dobývala Uhry zpět, byl zaznamenán pohyb obyvatelstva utíkajícího před jejím postupem zpět na Balkán, důsledkem čehož byla depopulace Uher.

Když se znovu podíváme na situaci Polska, hlubší příčinou úpadku se tu zdá být přílišná expanze země v 15. a 16. století, která zabránila efektivní centralizaci a vytvoření absolutistického státu, což byl zásadní předpoklad, aby se jakákoliv země mohla stát plnoprávným hráčem raně moderní mezinárodní politiky. Za vlády Jana Kazimíra (1648-1668) se objevovaly již první náznaky krize a v roce 1686 ztratila Reczpospolita první území. Následkem válek, epidemií a ztráty území se nakonec její populace zmenšila oproti „zlatému věku“ $z$ deseti na šest milionů obyvatel počátkem 18. století. Již v roce 1656, poprvé od dob plánů Zikmunda Lucemburského, byl vypracován plán rozdělení Polska mezi Švédsko, Braniborsko, Sedmihradsko a Ukrajinu, načež záhy následovaly další dohody o dělení Polska mezi jeho různými sousedy (Švédsko a Braniborsko 1667, Rakousko a Rusko 1675). Polsko tak postupně přestávalo být subjektem mezinárodní politiky a stávalo se jeho objektem. Zatímco v západních zemích začal tehdy posilovat merkantilismus a s ním spojený nárůst moci státu, Polsko nedokázalo tuto tendenci napodobit. Slabý stát nezvládal organizovat stavbu cest nebo průplavů a nepříznivý politický a ekonomický vývoj měl za následek úpadek polské vědy a částečně též kultury, ačkoli novější bádání ukazuje na značný kulturní rozkvět za časů saských králů. Jak píše Samsonowicz, zatímco v 18. století se západní přírodní věda stávala newtonovskou, učenci na polských univerzitách stále dokazovali neplatnost Koperníkovy heliocentrické teorie. V prostředí polské šlechty převládaly v 18. století ještě sarmatistické iluze, zatímco západní Evropa se propracovávala k osvícenskému racionalismu [Samsonowicz 1997: 133].

Poslední příčinou, která přiměla výše zmíněné sousedy započít v 70. letech 18. století dělení Polska, byla snaha Sejmu provádět reformy. Jak v tomto kontextu pregnantně poznamenává Kochanowicz, nikoliv tedy zaostalost a anarchie, ale naopak snaha zaostalost a anarchii překonat [Kochanowicz 1989: 115]. Poslední polská ústava z roku 1791 ještě stihla zrušit zásadu liberum veto, která po několik staletí činila polský sejm prakticky usnášení neschopný, a zbavila politických práv početnou šlechtu, jež nevlastnila půdu. Naopak poskytnutím politických práv všem, kdo měli majetek ve formě domu či půdy, nabídla politická práva měštanům. Ústava ovšem nestihla vejít v platnost a stala se jakousi závětí první polské republiky. Velmoci, které si rozdělily Polsko, nicméně farizejsky 
argumentovaly tím, že jsou nuceny si zemi podělit, aby zamezily anarchii a překonaly její zaostalost.

Z předchozích argumentů vyplývá, že úpadek Polska byl co do svých příčin zřejmě multikauzální záležitostí. Zapojení Polska do mezinárodní ekonomiky v 16. století pro něj snad poněkud připravilo půdu, ačkoli se mnozí historici dnes domnívají, že zemi spíše obohacovalo. Východní expanze země v 15. a 16. století vedla dlouhodobě k přetížení státní správy a posílení odstředivých tendencí aristokracie. Centralizace tak obrovského celku byla dále ztěžována nízkou hustotou obyvatel a špatnými cestami, což naopak podporovalo odstředivé tendence magnátů [Kochanowicz 1989: 116]. Expanze i zapojení do mezinárodního obchodu přispěly ke vzrůstu moci aristokracie a úpadku státu, rolnictva a měst. V 17. století pak následovaly dva další faktory: nástup moderních armád vytvářených nikoli z žoldnéřů, ale brannou povinností a pokles zájmu o polské obilí. K tomu se nově přidalo působení dvou mocných sousedů: Pruska a Ruska.

Pro všechny tři zkoumané země stejně jako pro většinu Evropy platí teze o krizi 17. století. V tomto případě však musíme rozlišovat dva fenomény: široce diskutovanou a dnes spíše odmítanou představu krize vyplývající z „periferního“ postavení regionu od počátku existence moderního světového systému a k tomu celkovou krizí Evropy v 17. a první polovině 18. století. Všechny tři země zažily během 17. století populační pokles, přičemž v Polsku, v Čechách i v Uhrách je možné hledat příčinu ve válkách 17. století, v Uhrách ale dosáhla depopulace největšího rozsahu. Zatímco na konci 15. století měla tato asi 5 milionů obyvatel, podle sčítání provedeného po osvobození Uher v roce 1720 zde žilo jen 2,58 milionů lidí6 [Janos, 1982] a v samotném Budíně a Pešti jenom 12 tisíc! V té samé době se počet obyvatel českých zemí a Polska v dnešních hranicích zdvojnásobil, stejně tak jako počet obyvatel Prahy a Krakova, nebot ztráty z válek 17. století, které představovaly maximálně třetinu obyvatelstva, se podařilo rychle vyrovnat. Ovšem také v uherském př́padě byly ztráty rychle vyrovnány: do roku 1787 se i díky emigraci z Balkánu populace Uher opět zvýšila na 8 milionů. Osmanská okupace rovněž změnila početní poměry mezi mad’arským a nemad’arským obyvatelstvem ve prospěch Nemad’arů, kteří žili většinou v nepřistupných horách, a byli tudíž ušetřeni bezprostředních následků osmanské invaze, a zároveň srbští a rumunští obyvatelé do Uher emigrovali před osmanským útlakem. Podle mad’arských historiků žilo v Uhrách na konci 15. století $80 \%$ mad’arského obyvatelstva a pouhých 20 \% připadalo na Slováky, Rusíny a Rumuny (ovšem není jisté, jaký byl početní poměr mezi domácími obyvateli a příchozími Madary v dobách jejich vpádu počátkem 10. století). Teprve nájezdy Turků do uherských rovin a vylidnění mad’arsky mluvících oblastí tento poměr změnily. V roce 1720 jen $44 \%$ obyvatel Uher hovořilo mad’arsky a $\mathrm{z}$ důvodů imigrace se počet Mad’arů v Uhrách dále snížil asi na $30 \%$ do roku 1787 [Janos 1982: 10]. Zde se nabízí srovnání s obyvatelstvem Čech a Moravy, kde se počet německých obyvatel mohl na konci 15 . století pohybovat okolo $15 \%$ a teprve zničení úrodných nížin s česky mluvícím obyvatelstvem ve třicetileté válce, respektive nová kolonizace horských oblastí v 16. století zapřičinily posun jazykové hranice a růst počtu německy hovořícího obyvatelstva až na $35 \%$ populace na konci století osmnáctého. Před ztrátou Slezska ve válkách o dědictví rakouské mohl být podíl českého etnika na obyvatelstvu Zemí koruny české

6 Kontler uvádí poněkud jiná data: $\mathrm{v}$ roce 1500 i v roce 1686 měly Uhry 3,5 milionu obyvatel [Kontler 2001: 174]. Také jeho data nicméně potvrzují tezi o demografickém úpadku země v 16. a 17. století. 
jen něco přes $50 \%$. V Polsku na rozdíl od Mad’arska a českých zemí neexistoval zdaleka tak výrazný protiklad mezi etnickými Poláky a nepolskými národnostmi s výjimkou Židů a Němců, nebot’ v zemi se spíše nacházela celá řada dialektů více či méně podobných polštině. Zvláště východním směrem nebylo příliš zřetelné, kde končí polské osídlení a začíná ukrajinské či běloruské. V době trojího dělení Polska byl podíl etnických Poláků na obyvatelstvu původní Reczpospolity uváděn $27 \%$ [Atlas... 2004: 83]. Také Polsko 18. století je proto možné podobně jako Uhry a české země považovat za multietnické, což představuje důležité specifikum celého regionu.

Jak dobře víme, v Čechách byla snaha šlechty o proměnu země na šlechtickou republiku neúspěšná. Zatímco v Polsku aristokracie zemi ovládla, byla od husitských válek mocná česká šlechta za stavovského povstání poražena a ztratila svůj vliv. Uhry se z tohoto hlediska nacházejí kdesi uprostřed: podobně jako v Čechách se rovněž v Mad’arsku odehrávala během osmanské nadvlády i krátce po osvobození stavovská povstání proti centrální moci Habsburků, ovšem na rozdíl od Čech úspěšná. Jejich konečným výsledkem byl kompromis mezi panovnickou mocí a šlechtou dojednaný tzv. Szatmárskou smlouvou (1711) a potvrzený pragmatickou sankcí v roce 1722. Habsburkové sice získali výlučné právo na mad’arský trůn, ale museli se o moc dělit se stavovským shromážděním šlechty [Janos 1982]. Naopak pozdější dělení Polska připomene skutečnost, že podle této smlouvy bylo z pravomoci Uher vyňato a Vídni přímo podřízeno Sedmihradsko stejně jako tzv. vojenská hranice s Osmanskou říší [Křen 2005: 58].

V kontrastu s českými zeměmi se v Polsku a v podobné míře v Mad’arsku udržel do novověku vysoký podíl svobodného obyvatelstva, které však představovalo spíše brzdu než modernizační potenciál. Početně silně zastoupená svobodná šlechta považovala jakýkoliv obchod či manuální zaměstnání za sobě nehodné a měla zájem spíše o vojenskou službu nebo státní správu. Početní svobodní rolníci zase neměli prostředky na zavádění nových technologií do zemědělské výroby. V této souvislosti se odhaduje, že skupina svobodných obyvatel mohla tvořit v polovině 18 . století $20 \%$ populace Uher a Polska [Davis 2003: 304], podle dat z českých zemí šlo asi o $7 \%$ procent celkového počtu obyvatel [Horská 1996: 229]. Drobná šlechta vymizela v českých zemích po třicetileté válce a do té doby svobodné skupiny sedláků pověřených ostrahou hranic byly úspěšně znevolňovány (Chodové), nebot nikdy nebyly tak početné jako v uherském př́ípadě. Vylidnění měst po třicetileté válce také snížilo podíl měštanů na obyvatelstvu, ačkoli ten byl od středověku vyšší než v Uhrách a Polsku.

Nárůst drobné šlechty v Uhrách i Polsku byl dán vysokou potřebou bojovníků v četných válkách 16. a 17. století, protože ti byli za své služby po skončení bojů povyšováni do šlechtického stavu. Je přitom dokonce možné, že ve válečných zmatcích byla celá řada šlechtických glejtů prostě zfalšována. V roce 1787 bylo v Uhrách 389 tisíc šlechticů, ale v roce 1839 už 617 tisíc, což představovalo pět procent populace země. Mezi šlechtici byly zároveň velké majetkové rozdíly: magnáti drželi početná panství, zatímco drobná šlechta jenom jednotlivé vesnice, někdy dokonce drželo jednu ves i víc šlechticů dohromady [Janos 1982: 19]. Relativně početné bylo po osvobození z osmanské okupace měštanstvo, většinou se jednalo o měštany nemad’arského původu, převažovali mezi nimi Židé, nebo Němci, nepočetní mad’arští obyvatelé měst byli převážně protestantského vyznání (např́íklad obyvatelé Debrecínu a Komárna). Silnou sociální skupinou představovali v Uhrách svobodní sedláci, kteří tvořili v 18. a století okolo $13 \%$ populace [Janos 
1982: 22]..$^{7}$ Naopak slabší byla tradičně církev, jenž disponovala pouze $12 \%$ feudálních lén. Rovněž pozice poddaných byla v Uhrách v novověku lepší než ve zbytku středovýchodní Evropy, ačkoli v 16. století probíhal i zde proces znevolňování. V 18. století došlo k obratu v souvislosti s vylidněním země a tedy ve spojení se stoupající cenou zemědělských prací. O další zlepšení pozice poddaných se pak v Uhrách podobně jako v českých zemích zasloužila Marie Terezie spolu s Josefem II.

Zdá se, že samotná osmanská správa Uher nebyla pro zemi takovou ekonomickou katastrofou, za jakou se obvykle pokládá. Jak uvádí Janos, některé části byly sice zničeny válkou, nicméně jiné profitovaly z poptávky osmanských vojsk po potravinách a nástrojích, nebot’ relativně rozvinuté Uhry hrály roli ekonomického centra přinejmenším balkánské části osmanské ŕíše a $\mathrm{z}$ tohoto postavení profitovaly. Proto byl podle Janose katastrofou spíše konec osmanského panství, kdy byly Uhry připojeny k habsburským državám jako jejich podřízená část a císařské obchodní tarify jejich pozici ještě zhoršily: na zboží dovážené z Uher do rakouských zemí byla od roku 1756 uvalena daň $10 \%$, zatímco zboží putující z Rakouska do Uher bylo zatíženo jen dvouprocentní daní. Zboží dovážené ze zahraničí do Uher bylo postiženo dokonce daní ve výši 33,3\%. Od roku 1775 museli navíc uherští kupci vyvážející zboží do Německa přes rakouské země, zde zaplatit daň, zatímco rakouští kupci dopravující zboží do Transylvánie přes Uhry nic neplatili. K tomu se přidalo vytěžení drahých kovů, které po staletí zaručovaly Uhrám pozitivní bilanci v zahraničním obchodě [Janos 1982: 31] a hospodářský úpadek byl nevyhnutelný: zatímco na konci tureckých válek v roce 1699 žilo v mad’arských městech $15 \%$ populace, v roce 1787 už to bylo jen $5,7 \%$ (70 svobodných měst obývalo celkem 498 tisíc lidí) a více než polovina $\mathrm{z}$ tohoto počtu se už věnovala zemědělství. Úpadek uherských měst pokračoval až do poloviny 19. století a do roku 1837 se podíl jejich obyvatel dále zmenšil na $5 \%$ [Janos 1982: 77-78]. Podobně jako v českých zemích po Bílé hoře, i v Mad’arsku během 18. století města ztratila svůj politický vliv. Ještě v 17. století byla rovnocenným stavem v poměru ke šlechtě na zemském sněmu, ale v 18 . století byla reprezentace měst již zmenšena na jeden hlas oproti 55 hlasům šlechty.

Zvýšená poptávka po obilí v 18. století v západní Evropě způsobená růstem západních měst, kterou již nemohl uspokojit dovoz obilí z Baltu či z Ruska, vedla ke snahám rakouského státu zlepšit možnosti dovozu obilí též z Uher, a to především splavňováním řek a budováním cest. Když hrabě Kounic (1711-1794) přikázal stavět říční kanály z Uher do Rakouska, začal export uherského obilí převyšovat export dobytka a během několika málo desetiletí se tak Uhry staly ze země pastevců zemí převážně rolníků. Rakouský stát se navíc pokoušel zbavit Uhry i jejich řemeslníků, nebot’ se podle představ merkantilistů měla řemeslnické a manufakturní výrobě věnovat západní polovina říše, která k ní měla lepší předpoklady. V roce 1756 stanovila vláda systém cel pro obchod Rakouska s Uhrami tak, aby byl z Rakouska podporován vývoz hotových výrobků, zatímco z Uher

Tito obývali několik oblastí považovaných za svobodné. První byli Szekelové (Sikulové), což byl jeden z mad’arských kmenů, jehož úkolem bylo od počátků mad’arského státu stř̌ežit jeho východní hranici. Druhý region byl založen ve třináctém století ve středních Uhrách, kdy se zde usadily kmeny Kumánů a Jazygů, které byly osvobozeny od feudálních povinností a na oplátku se zavázaly bránit území říše. Třetí skupinu tvořili tzv. hajduci, loupeživí pastevci různého etnického původu, které usadil v 17. století vévoda Bočkaj v okolí Debrecínu, od čehož si sliboval jejich pomoc v bojích s císařem. Rakousko tuto situaci napodobilo a vytvořilo tzv. vojenskou hranici na pomezí s osmanskou říśí, kde bylo zdejší chorvatské, srbské nebo rumunské obyvatelstvo pod př́mou správou vídeňského ministerstva války. 
zemědělských plodin. Merkantilizmus ovšem narazil na odpor uherské šlechty, jež se obávala oslabení svého postavení růstem moci obchodníků a měštanů. Zatímco tedy čeští šlechtici byli po porážce na Bílé Hoře vưči rakouskému státu celkem loajální a nebránili merkantilistickým reformám, mad’arská šlechta měla větší moc a dokázala zabránit mnoha modernizačním opatřením [Stokes 1989: 221]. Úpadek uherských měst v kombinaci s překážkami vytvářenými šlechtou ale postihl do důsledků i uherské zemědělství, nebở se ukázalo, že dovoz obilí po říčních kanálech nemůže být alternativou zapojení Uher coby producenta masa a vína do evropské ekonomiky 16.-18. století. Uherští zemědělci proto opustili na konci 18. století trojpolní systém a vrátili s k dvojpolnímu. V téže době došlo k opuštění trojpolního systému také v Čechách, ovšem ve prospěch modernějšího systému střídavého, kombinujícího obilí s bramborami nebo pícninami, což umožnilo další nárůst zemědělské produkce [Fialová, Kučera, Maur 1996: 178]. V Uhrách se tehdy též zmenšilo užívání peněz, královská komise např̀ v roce 1783 informovala panovníka, že mnoho obcí chce raději platit daně v naturáliích [Janos 1982: 33]. Uhry vstoupily do moderní doby podobně jako Polsko a na rozdíl od českých zemí coby v evropském měřítku velmi zaostalá země. Můžeme tudíž shrnout, že příčinou úpadku Uher patrně nebyla ve větší míře jejich „periferializace“ v rámci evropské ekonomiky 16. století, významější roli sehrál přílišný nárůst moci šlechty, válečné operace během 16. a 17. století a teprve poté začlenění Uher do habsburské říše jako jejího zemědělského zázemí v první polovině století osmnáctého a zároveň v té samé době odpor uherské šlechty vưči jakékoli modernizaci.

Úpadek celého regionu v 17. a 18. století zachycují zprávy zahraničních návštěvníků ze západní Evropy, kteří bývali často šokováni tamní bídou. Toto platí nejenom o Polsku a Uhrách, ale do jisté míry též o českých zemích. Jak ukázala Radiměřská [2008], ještě v 17. století nebylo na tento region pohlíženo jako na barbarské oblasti protikladné k evropské civilizaci, například angličtí cestovatelé vnímali hranici mezi křestanstvím a islámem, prrípadně postupně s pohybem na východ se zhoršující poměry v Evropě „na východ od Rýna“, což snad souviselo s velmi poničeným územím německé rríše za třicetileté války. Tato situace se ale mění od počátku 18. století, kdy Polsko začalo být tehdejšími západními návštěvníky považováno za zemi nejhlubšího barbarství a zaostalého hospodářství, jehož poměry „dokonce překonávají Turecko“ [cit. dle Wolf 1996: 138]. Podobně se na adresu Polska vyjadřoval Friedrich Veliký: „Města v žalostném stavu. Například Kulm (Chelmno) by měl mít osm set domů, ale ve skutečnosti jich není víc než sto, bydlí tam bud' Židé nebo mniši. A všude mnoho bídy [cit. dle Stellner 1998: 410]. “Dvůr Stanislava Lesczynského v Královci roku 1735, kam byl tento panovník vyhnán z Varšavy ruskými vojsky, se vyznačoval podle téhož zdroje „úplatkářstvím, špínou a neznalostí cizích jazykü“ [cit. dle Stellner 1998: 92].

Stejně hovoří o Polsku William Coxe (1747-1828) ve své knize Cesty po Polsku, Rusku, Švédsku a Dánsku (1784): „Cesty byly špatné, vesnic bylo málo a byly nepředstavitelně zbídačené [...] chatrče postavené ze dřeva se zdály být plné špíny a mizérie a vše se zdálo být dokladem strašlivé bídy [...] Nikdy jsem neviděl tak nudnou cestu, jako je z Krakova do Varšavy. Během cesty není ani jedna věc, která by mohla alespoň na chvíli zaujmout pozornost zvídavého cestovatele“ [cit. dle Wolff 1996: 26-27]. O Varšavě pak napsal: „Celé město má melancholický zjev, ukazujíc velký kontrast mezi bohatstvím a chudobou, luxusem a bídou, která se rozprostírá po celé této neštastné zemi. Ulice jsou sice prostorné, ale špatně vydlážděné, kostely a veřejné budovy jsou velké a výstavné, paláce šlechty jsou 
početné a skvělé, ale největší část domů, hlavně na předměstích, je tvořena bídnými a špatně stavěnými chatrčemi“ [cit. dle Wolf 1996: 28]. Celková charakteristika zní takto: „Poláci svými rysy, zjevem, zvyky a celkovým dojmem připomínají spíše Asiaty než Evropany a bezpochyby pocházejí ze svých tatarských předchůdcü“ [cit. dle Wolf 1996: 29].

Johann Gottfried Herder napsal roku 1798 báseň o svrženém polském králi Stanislavu Lesczynském, v níž se dočteme, „že může být štasten ze ztráty Polska, nebot taková země nebyla hodná osvíceného panovníka" [cit. dle Wolf 1996: 333]. Johann Gottlieb Fichte zase píše na své cestě z roku 1791, že pro něj začíná Polsko již ve Slezsku, kde viděl vesnice „horší než saské a zdají se být velmi polské“ [cit. dle Wolf 1996: 333]. Za Vratislaví se mu už pole jevila méně kultivovaná, lidé „více slovanští“ a jazyk „hrubší i polské ulice jsou špinavé, plné „slámy, odpadků a hnoje“ [cit. dle Wolf 1996: 335]. Množí se popisy všeobecného opilství, surového nakládání s rolníky, luxus šlechty přecházející až k rozhazovačnosti, nedostatek tvořivého myšlení, napodobování všeho cizího. Při četbě těchto zápisků je ovšem třeba mít na paměti, že cestovatelé dost často na polském př́íkladu chtěli jinotajně poukázat na neutěšené poměry v jejich vlastní zemi, př́padně se snažili hlavně šokovat čtenáře, a proto zmiňovali jen extrémní př́ípady [Wolf 1996: 138].

Popisy mad’arské zaostalosti se dostávají do evropského učeného diskurzu poněkud později než v př́padě Polska. Ještě v 18. století považovali západoevropané podle Janose Uhry za zemi sice exotickou, ale krásnou a bohatou na př́rodní zdroje. Uhry tehdy přitahovaly početné kolonisty především z německých krajů, což se mění na konci století. Uhry přestávaly být zemí ověnčenou aureolou bojovníka proti Turkům a stávaly se zemí bídy a zaostalosti. Cestovatelé 18. století upozorňují na zdejší bídné cesty, které na rozdíl západní Evropy nebyly zpevněné, ale tvořily je pouze koleje vyježděné vozy, sklo v oknech představovalo raritu a většina sídel šlechty byla ze dřeva. Lepší oblečení, dovážené tehdy z Moravy, se považovalo za natolik vzácnou komoditu, že se dědilo z generace na generaci, přešívalo, a když bylo zcela roztrhané, alespoň knoflíky se použily na nové. Angličané, kteří Uhry navštívili, aby zde sondovali možnosti vzájemného obchodu, byli stavem země naprosto zděšeni. Vysvětlení cestovatelé obvykle hledali v charakteru zdejších obyvatel. Tak Francouz Marcel de Serres napsal, že Mad’aři jsou od př́rody indolentní a upřednostňují pastevecký život před rolnictvím. Ačkoliv je Mad’arsko úrodnou zemí, jeho obyvatelé nemají žádnou představu, jak využít těchto zdrojů v půdě a ve své ignoranci a pověrčivosti jsou stejně špatnými zemědělci jako obchodníky. Obraz země coby zaostalé lokality tak počátkem 19. století jednoznačně převážil [Janos 1982: 34].

Diskurz zobrazující Čechy jako válkou rozvrácenou a zaostalou zemi se prosazuje již po třicetileté válce. $\mathrm{V}$ ní patřily české země k územím poničeným více než Polsko a Uhry, kde byla depopulace sice vyšší nežli v rakouských zemích, ale nedosahovala rozměrů jihoněmeckého Würtenberska a Falce nebo severoněmeckého Meklenburska [Maur 1996: 101]. Snad k obrázku zaostalosti přispěla též absence domácích elit a existující sociální propast mezi spíše nečeskou vládnoucí vrstvou a českou většinou. Možná že v kontinentálním klimatu českých zemí byla obzvláště patrná ona malá doba ledová, o které hovoří v 17. století klimatologové. Není to tedy jenom devastace země válkou a z ní plynoucí zaostalost, ale již samotné přírodní klima českých zemí se najednou začíná jevit mnohem drsnější, než tomu bylo dřive: „Podnebí tam je obecně velmi nezdravé, píše se v letopisu z roku 1691 [cit. dle Kašparová 2003: 107]. Negativního stereotypu Čech jako chladné země si byli vědomi i mnozí její obyvatelé, tak např́klad hrabě Karl Sweerts-Špork 
ve svém německém spisku Jak by se mohlo milé vlasti od značného úpadku poněkud odpomoci (míněny Čechy), vydaného po roce 1740 se snaží vyvracet názor, že je země studená, chladná, drsná a nehostinná, a naopak argumentuje tím, že by u nás šly pěstovat i citróny a pomeranče [cit. dle Haubelt 1986: 145]. Více než v minulosti je v této době zahraničními návštěvníky zmiňována kriminalita a špína: „Nikdo se nemůže odvážit jít v noci po Praze, aniž by byl okraden, a na venkov není možno většinou cestovat jinak než ve skupině 30 či 40 lidí, ze strachu před lupiči“ [cit. dle Kašparová 2003: 107]. V téže době bylo mezi aristokracií zvykem cestovat po Čechách na rozdíl od německých či rakouských zemí ve dvou kočárech - v jednom jel pán a ve druhém byly složeny matrace a kuchyňské náčiní, nebở se našlo jen málo míst dostatečně komfortních [cit. dle Mat’a 2002: 79]. „V Rakousích člověk potká vesnice častěji než v Čechách a v lepším stavu“, psal jiný návštěvník na konci 17. století [cit. dle Mat’a 2002: 81]. I Friedrich Veliký vnímal české země ve srovnání s rodným Braniborskem jako zaostalejší. Ve svém popisu Moravy uvádí lapidárně: „Viděl jsem tam domy s rovnými střechami jako v Itálii, velmi špinavé ulice, př́kré hory, hodně vinic, mnoho hloupých mužů, ošklivých žen a dost mladých oslů. To je Morava ve zkratce" [cit. dle Stellner 1998: 144]. Podle anglické autorky Hester Lynch Piozzi bylo zpoždění českých zemí, pokud jde o oblečení obyvatel v roce 1786, zpožděno za Anglií tak 80 let [Konvičná 2006: 193].

Kriticky vyznívají také popisy obyvatelstva, kupříkladu česká šlechta byla na konci 18. století viděna francouzskými návštěvníky jako „lenivá, marnotratná, ubíjející svůj čas klábosením a lovem“ [cit. dle Maur, Chrobák 2005: 239-240]. Většina francouzských cestovatelů explicitně označovala českou zemi za „chudobnou“ [Maur, Chrobák 2005: 240], jeden Francouz dokonce již v letech 1738-1740 přirovnával Čechy k Asii, což bylo jinak v porovnání s Polskem nebo Uhrami poměrně řídké přirovnání. Tvrdil, že otroctví českých rolníků „se neliší od otroctví asijských národů jen s tím rozdílem, že nejsou voděni na veřejné trhy k prodeji“ [cit. dle Maur, Chrobák 2005: 241]. Podobně šokovaly francouzské návštěvníky i další znaky zaostalosti - bigotní katolicizmus a velké sociální rozdíly: lidé se prý v roce 1779 v Praze modlili „s takovou horoucností, že se jí zejména člověk přijíždějící z Berlína nestačí divit“ [cit. dle Maur, Chrobák 2005: 242]. Čeští měštané prý nevycházeli na ulici bez služebníků, více než na Západě pak bylo rozšířené líbání rukou - děti líbaly ruce rodičům, služebníci pánům, chudobní dobrodincům [Maur, Chrobák 2005: 245].

Naopak zase návštěvníci z východní Evropy považovali Čechy v 18. století za vyspělejší než svoje vlastní země. Polští cestovatelé oceňovali již v 18. století kvalitu moravských silnic, kudy velmi často putovali do Ríma nebo do Francie (Čechy většinou nebývaly cílem jejich cesty). Silnice mezi Vídní a Olomoucí byla jedním polským cestovatelem charakterizována v roce 1768 „jako široká a dlážděná“ (navíc zdưrazněno, že „takové silnice jsou všude v rakouských státech") a lemovaná krásnými alejemi ovocných stromů. V téže době překvapovalo běloruského cestovatele množství zděných a hrázděných domů, nebot' byl z domova zvyklý na dřevěné stavby. Jsa profesí klerik, zmiňoval též, že ho zaujalo bohatství klášterů - do josefínských reforem zbývalo ještě jedno desetiletí - „V porovnání s nimiž naše kláštery kurníky zvány býti mohou“ [cit. dle Rok 1999: 322]. Selská stavení na českém a moravském venkově se ale polskému cestovateli Ossolińskému zdála v roce 1792 o poznání horší než v rakouských zemích. Naše země se podle něj nacházely z hlediska rozvoje někde mezi Haličí a rakouskými zeměmi. Praha byla ve srovnání se západoevropskými městy špatně osvětlená a málo dlážděná [Mikulka 1976: 331]. 


\section{Závěr}

Polské, uherské a české království společně sdílejí i ztrátu nezávislosti během procesu vytváření novověkých absolutistických mocností v 16.-18. století. Ani jedna z těchto zemí se nedokázala stát jádrem podobného procesu a ve všech existovala počátkem 16. století př́liš silná šlechta, která nedovolila panovnickou centralizaci. Tyto tři státy ztratily nezávislost proto, že ani v jednom $\mathrm{z}$ nich se nezdařilo vybudovat novověkou absolutistickou monarchii, a naopak jejich sousedé, tedy Prusko, Rakousko i Rusko v tomto uspěly, a náš region se tak stal obětí jejich územní expanze. Je možné jen spekulovat, nakolik měly Uhry předpoklad pro vznik absolutistického státu, pokud by se bývala nedostavila osmanská invaze. Možná že by se býval také mohl zdařit proces budování absolutní monarchie a Uhry by se staly pod vládou Jagellonců protiváhou mocenských ambicí Habsburků, případně by centrum sjednocení střední Evropy do podunajské monarchie vzešlo právě odsud. Možná by však Uhry sdílely spíše osud Polska a staly by se podobně rozhádaným a stagnujícím celkem. Osmanská invaze nicméně zničila jakékoli dějinné alternativy a oslabené, zbytkové Uhry se staly součástí Habsburské domény, ačkoli jejich původní síla vedla alespoň k zachování významného postavení v rámci tohoto svazku. Z uherské státnosti toho tedy v 18. a 19. století zbylo ve srovnání se státností českou a polskou nejvíce. Ačkoliv nebyla česká státnost oslabena invazí vnějšího nepřítele jako ta uherská, protestantský a neněmecký charakter českých zemí způsobil, že se v rámci habsburských držav ocitly již v 16. století ve vedlejším postavení, přestože byly větší, lidnatější a patrně i mírně vyspělejší než alpské země (s výjimkou Podunají). Praha se nestala hlavním městem rakouského soustátí, s výjimkou krátkého intermezza za Rudolfa II. Obnovené zřízení zemské dále oslabilo postavení českých zemí, stejně jako zrušení české dvorské kanceláře v rámci centralizačních snah Marie Terezie. Poláci ztratili státní nezávislost nejpozději, teprve na konci 18. století, avšak tato ztráta byla ze srovnávaných zemí nejrychlejší a nejvýraznější: ani v Čechách, ani v Uhrách nedošlo ke zrušení království se všemi jeho institucemi jako v polském prrípadě. Panovníci domu habsburského se stávali českými nebo uherskými králi, zatímco ve zbytkovém Polsku bylo vyhlášeno nejprve Napoleonovo Velkovévodství varšavské, poté formální království pod svrchovaností ruského cara, a nakonec pouhá ruská gubernie. Polským neštěstím se stalo sousedství tři silných expanzivních mocností, takže byla mezi ně země rozdělena a nikoli spojena personální unií s jednou z nich jako v prrípadě Uher či českých zemí. Naopak, na rozdíl od osudu českých zemí, zůstal pro velkou část evropské veřejnosti zánik Polska historickou anomálií a během celého 19. století se očekávala jeho budoucí obnova. Rovněž slavné body presidenta Wilsona z konce první světové války obsahovaly požadavek obnovy Polska, zatímco pro národy Rakouska-Uherska předpokládaly pouze autonomii.

Závěrem si musíme ještě položit otázku, nakolik je uvažování o regionu tvořeného Polskem, Uhrami a českými zeměmi přínosné pro historicko-sociální výzkum středověku a raného novověku a zda by nebylo vhodnější i nadále brát za jednotku analýzy bud' jednotlivé státy, nebo celý evropský kontinent. Námitka, kterou můžeme očekávat, používáme-li tento region jako svou jednotku analýzy ve středověku a raném novověku, spočívá v tom, zda vlastně neaplikujeme na vzdálenou minulost perspektivu 20. století, kdy měly Polsko, Mad’arsko a Československo podobný osud. Jednalo se totiž o oblast se západní křestanskou tradicí, kde se jednotlivé státy znovuobjevily jako nezávislí aktéři na mezinárodní 
scéně v důsledku rozpadu impérií po první světové válce, po druhé světové válce se staly obětí stalinské expanze a na přelomu tisíciletí byly jako první země postsovětského prostoru přijaty do NATO a Evropské unie. Podobný osud sdílelo s jistými výhradami pouze Chorvatsko a Slovinsko na jihu, respektive Pobaltí na severu.

Jak jsme si ukázali, můžeme nalézt ve středověku a v raném novověku řadu společných vývojových tendencí tohoto regionu, ovšem rovněž zaznamenáme mnohé rozdíly. Především byl tento region v podobné době „opožděně“ christianizován ze Západu a vznikly v něm státy místních válečnických elit. Dále Polsko a český stát prošly svou raně středověku krizí, byt’ v uherském př́padě byla způsobena až později útokem Mongolů. Všechny tři země zažily zlatý věk ve 14 . století a postupné oslabování panovnické moci, v Čechách a Uhrách se tak dělo od 13. století, zatímco v Polsku měl tento proces hlubší kořeny. Všechny tři zkoumané země byly integrovány do rychle se rozvíjející evropské ekonomiky 16. století (zvláště ale Polsko okolo pobřeží a říčních toků), třebaže v Čechách byl tento proces méně zřetelný a v uherském př́ípadě došlo $\mathrm{k}$ jeho narušení osmanskou invazí. Konečně v celém regionu se od 16. století dostavuje ekonomická krize, která předchází zániku státnosti těchto zemí.

Najdeme však rovněž důležité rozdíly: je to především významné postavení Polska a Uher na počátcích jejich dějin, významné postavení Uher ve středověkém systému evropských států 10.-13. století a Polska v raném novověku. Mocenské úspěchy obou zemí byly umožněny relativně snadnou expanzí do méně rozvinutých oblastí. Dále pak jsou tu útoky neevropanů, konkrétně Mongolů ve 13. století a Turků v 16.-17. století, které představují specifikum dějin Uher. Nejdůležitější české specifikum představuje zdejší reformace, jež pocházela na rozdíl od reformace polské a uherské z domácích zdrojů a získala na svou stranu většinu společnosti. Taktéž následná rekatolizace byla ovšem v českých zemích v porovnání s Polskem a Uhrami absolutní. Polským specifikem pak zůstává až do konce 18. století přetrvávající samostatnost. Pokud by se bývali nevyskytli mocní sousedé, je možné, že by polská státnost přežila do 19. století, stejně jako se uchovala státnost španělská, tedy v podobě státu, jehož instituce se více a více stávaly reliktem minulosti a rezervací středověku. Polská státnost byla na rozdíl od státnosti české a uherské nakonec zcela odstraněna, když předtím selhaly pokusy švédských Vasovců nebo saských Wettinů budovat dlouhodobé personální unie mezi jejich původními zeměmi a Polskem, nebở země se ukázala být př́liš velkou a obtížně zvladatelnou k takovému kroku. To kontrastuje s podmínkami Uher nebo českých zemí, které se Habsburkům podařilo sjednotit a relativně centralizovat, byt tím patrně vložili své monarchii do vínku příčiny jejího budoucího zániku.

Z hlediska míry ekonomického rozvoje není možné náš region zcela paušálně označit za periferii Evropy už od 16. století, jak činil v 70. letech Wallerstein, ostatně i on sám ve čtvrtém, nejnovějším díle svého Moderního světového systému z roku 2011 již daný koncept prakticky nepoužívá. Hlavním důvodem, proč se například Eduard Maur zdráhá tento koncept akceptovat, je nepochybná skutečnost velkých ekonomických rozdílů v rámci regionu. Některé zóny, jako české země, slovenská Spiš, západní Uhry nebo polské Malopolsko a Pobaltí od 13. století, jen mírně zaostávaly za raně novověkým Německem, takže by se dal označit spíše za semiperiferii [Maur 2002: 72-74], zbytek byl výrazně méně rozvinutý. V rámci celého regionu nenalézáme patrně s jistou výjimkou Pobaltí v 16. století nebo center těžby drahých kovů v Čechách a Uhrách př́klad podobně dynamického 
rozvoje, jaký zažila středověká severní Francie či severní Itálie. Krize 16.-17. století se přitom objevovala $\mathrm{v}$ námi zkoumaných zemích $\mathrm{v}$ různých okamžicích a v různém rozsahu: v českých zemích začala nejpozději a skončila nejdříve, takže spíše se dá mluvit o krizi první poloviny 17. století. V Uhrách začala naopak velmi brzy, a to již počátkem 16. století společně s osmanskou invazí a protáhla se nejdéle, náznaky ekonomického oživení budou patrné až na konci 18. století. V Polsku pak se objevila krize o něco později, až na konci 16. století, ale délkou svého trvání se podobá krizi uherské.

Také vědomí společných vazeb v rámci regionu během středověku a raného novověku spíše absentovalo, což problematizuje snahu hovořit o těchto třech zemích jako o jednom regionu. Polský a český stát hleděly v raném a vrcholném stř̌edověku primárně do německých zemí, Uhersko zase do Itálie a Francie. I když se vyskytly od 10. století pokusy soustátí v různých kombinacích spojit, byly až do 16 . století velmi krátkodeché a stála za nimi spíše krátkodobá expanzivní politika jednotlivých zemí než nějaký promyšlený regionální zájem. Vzpomeňme pokus sjednotit Čechy a Polsko Boleslava I. Chrabrého počátkem 11. století a Václava II. počátkem 14. století. Pak tu najdeme pokus spojit Čechy a Uhry za Zikmunda Lucemburského v 15. století, sjednotit Uhry a Polsko Ludvíkem I. ve 14. století a Ladislavem Varnenčikem v 15. století. Nalézáme zde ovšem i rozsáhlejší projekty: snahu Václava III. spojit pod svou vládou Uhry, Čechy a Polsko, úsilí Matyáše Korvína spojit v 15. století Uhry, Čechy a německou říši, snahu Jagellonců konce 15. století vytvořit česko-uhersko-polské soustátí, a nakonec úspěšnou snahu Habsburků o česko-uhersko-rakouskou personální unii. Rakouští Habsburkové moudře usoudili, že snaha připojit do jejich soustátí ještě polsko-litevský stát by byla příliš velkým soustem, a neopakovali tedy pokus Maxmiliána II. z roku 1575 přidat k české, uherské a říšské koruně ještě korunu polskou. Tak nastává od 16. století postupná divergence regionu, kdy se v jedné jeho části utváŕí habsburské soustátí coby syntéza českých, alpských zemí a zbytkových Uher, ovšem s převažujícím rakouským vlivem. Toto soustátí se krok za krokem centralizuje a zvláště jeho západní část se relativně úspěšně rozvíjí, ačkoliv expanzivní ambice monarchie končí počátkem 18. století [Anderson 1979: 309]. Ve druhé části regionu přetrvává polsko-litevský stát, který naopak stagnuje a upadá. Rakouský stát, postavený na poměrně solidních základech, přežil až do roku 1918, třebaže bylo již desetiletí předtím zřejmé, že dědictví rozdrobené středovýchodní Evropy bude př́liš tíživým břemenem. Naproti tomu po dvě století stagnující polsko-litevský stát se stal předmětem trojího dělení v letech 1772-1795, takže teprve rok 1918 znamenal obnovení stř̌edoevropské situace zhruba v té podobě, jaká existovala do počátku 16. století, tedy za existence nezávislého polského, českého a uherského státu.

Z výše vyjmenovaných společných vývojových trendů a odlišností dle mého soudu plyne, že středovýchodní či střední Evropa nemůže být ve středověku a raném novověku pokládána za natolik kompaktní region jako např. Skandinávie nebo pravoslavný Balkán, aby bylo možno jej používat jako analytickou kategorii a aby se mohl stát východiskem pro psaní větších syntéz. Zdá se velmi pravděpodobné, že bychom při srovnávání vývoje českých a německých zemí nalezli podobné množství shod a odlišností jako při komparaci českých zemí s Polskem a Uhrami. V prrípadě Polska by potom bylo možné vidět společné vývojové tendence od 14. století mezi ním a Litvou, respektive v prrípadě Uher od 11. století mezi touto zemí a Chorvatskem. Na druhou stranu se existence řady společných vývojových tendencí uherského, českého a polského státu ukazuje natolik zřejmou 
a zároveň málo diskutovanou, že zde komparativní perspektiva možná dosud nevyčerpala své možnosti. Zvláště české prostředí, které se s oblibou vždy porovnává se západními sousedy, může získat díky srovnávání s Polskem nebo Uhrami řadu zajímavých pohledů na sebe sama.

\section{Literatura}

Adamczyk, Dariusz. [2001]. Zur Stellung Polens im modernen Weltsystem der Frühen Neuzeit. Bez místa vydání: Kovac.

Anderson, Perry. [1974]. Passages From Antiquity to Feudalism. London: New Left Books.

Anderson, Perry. [1979]. Lineages of the Absolutist State. London, New York: Verso.

Andrén, Anders. [1994]. In. Tilly, Charles - Blockmans, Wim (eds.). Cities and the Rise of States in Europe A. D. 1000-1800. Boulder, San Francisco, Oxford: Westview Press.

Atlas historii Polski. [2004]. Warszsawa: Świat Ksiązki.

Bartlett, Robert. [2009]. Evropa a přemyslovský stát. In. Třeštík, Dušan - Josef, Žemlička - Petr, Sommer (eds). Přemyslovci, budování českého státu. Praha: NLN.

Cipolla, Carlo. [1994]. Before Industrial Revolution. European Society and Economy 1000-1700. London: Routledge.

Davis, Norman. [2003]. Polsko: dějiny národa ve středu Evropy. Praha: Prostor.

Dvorník, František. [1999]. Zrod střední a východní Evropy: mezi Byzancí a Římem. Praha: Prostor.

Elias, Norbert. [1939]. Über den Prozeß der Zivilisation. Basel: Verlag Haus zum Falken. (Česky: O procesu civilizace, sociogenetické a psychogenetické studie: proměny chování světských horních vrstev na Západě. Svazek 1. Praha: Argo, 2006.)

Haubelt, Josef. [1986]. České osvícenství. Praha: Svoboda.

Hloušek, Vít. [2003]. Evropa a její místo v dějinách - reflexe Oskara Haleckého. Středoevropské politické studie 4/2003.

Hloušek, Vít - Kopeček, Lubomír. [2004]. Konfliktní demokracie. Moderní masová politika ve střední Evropě. Brno: Masarykova univerzita, Mezinárodní politologický ústav.

Horská, Pavla. [1996]. Obyvatelstvo českých zemí podle povolání. In. Fialová, Ludmila a kol. Dějiny obyvatelstva českých zemí. Praha: Mladá fronta.

Janos, Andrew. [1982]. Politics of Backwardness in Hungary 1825-1945. Princeton: Princeton University Press.

Kašparová, Jaroslava. [2003]. Francouzské zeměpisné př́ručky a geografická kompendia druhé poloviny 17. století a obraz českých zemí v nich podaný. Knihy a dějiny 9/10, s. 90-120.

Kdo patří do střední Evropy? [1996]. Reflex 35/1996, s. 15.

Kochanowicz, Jacek. [1989]. The polish ekonomy and the evolution of dependency. In. Chirot, Daniel. (ed.). The origins of backwardness in eastern Europe. Berkley: University of California Press.

Kontler, Laszlo. [2001]. Dějiny Madarska. Praha: NLN.

Konvičná, Jana. [2006]. Praha konce 18. století očima cizinců. In. Praha Mozartova. Kulturní a společenský život v Praze 1780-1800. Publikace k výstavě. Clam-Gallasův palác, 21. listopadu 2006 - 28. ledna 2007. Praha: Archiv hlavního města Prahy, s. 188-197.

Křen, Jan. [2005]. Dvě století střední Evropy. Praha: Argo.

Malowist, Marian. [1954]. Studia z dziejów rzemiosła w okresie kryzysu feudalizmu w Zachodniej Europie $w$ XIV i XV wieku. Warszawa: Państwowe Wydaw. Naukowe.

Mann, Michael. [1986]. The Sources of Social Power: A History of Power from the Beginning to AD 1760. Volume 1. New York/London: Cambridge University Press.

Mata, Petr. [2002]. Čechy a Morava roku 1666 v cestovním deníku toskánského šlechtice Franceska Riccardiho. In. Mata, Petr a kol. O misera Boemia. In. Souvislosti, Revue pro literaturu a kulturu 13, č. 3-4, s. 73-82.

Maur, Eduard. [1996]. Obyvatelstvo českých zemí v raném novověku, třicetiletá válka. In. Ludmila Fialová a kol. Dějiny obyvatelstva českých zemí. Praha: Mladá fronta. 
Maur, Eduard - Chrobák, Tomáš. [2005]. Nový hlas Francouze o Čechách. (Popis Prahy a mravů jejích obyvatel z roku 1742). Folia Historica Bohemica 21, s. 235-264.

Maur, Eduard - Horská, Pavla - Musil, Jiří. [2002]. Zrod velkoměsta. Litomyšl: Paseka.

Mikulka, Jaromír. [1976]. Pobyt Josefa Maxmiliána Ossolinského v českých zemích. Slovanský přehled 62, č. 4, s. 329-334.

Nolte, Heinrich. [1993]. Die eine Welt: Abriss der Geschichte des internationalen Systems. Hannover: Fackelträger.

Nolte, Heinrich. [1997]. Evropský systém ve středověku - obhajoba souboru ukazatelů a nelineárního výzkum. In. Klusáková, Luda (ed.). Kritéria a ukazatelé nerovnomèrného vývoje. Praha: FF UK.

Radiměřská, Božena. [2008]. Evropa „na východ od Rýna“ na mentální mapě anglicky píšícího cestovatele sedmnáctého století. Českýlid, 1/2008.

Rok, Bogdan. [1999]. České země v povědomí Poláků v 18. století na podkladě zeměpisné a cestovatelské literatury. In. Východočeská duchovní a slovesná kultura v 18. století. Boskovice: Albert, s. 315-323.

Samsonowicz, Henryk. [1997]. Polens Platz in Europa. Osnabrück: fibre.

Stellner, František. [1998]. Friedrich Veliký, Cesta Pruska k velmocenskému postavení. Praha: Panevropa.

Stokes, Gale. [1989]. The social origins of East European Politics. In. Chirot, Daniel (ed.). The origins of backwardness in eastern Europe. Berkley: University of California Press.

Šmahel, František. [1995]. Husitská revoluce. Doba vymknutá z kloubů. Praha: Academia.

Tilly, Charles. [1992]. Coercion, Capital, and European States, AD 990-1992. New York/London: Blackwell.

Trávníček, Jiří. (ed.). [2009]. V kleštích dějin. Střední Evropa jako pojem a problém. Brno: Host.

Wallerstein, Immanuel. [1974]. The modern World-System I. Capitalist Agriculture and origins of the European World economy in the Sixsteenth century. New York and London: Academic press.

Wandycz, Piotr S. [1998]. Střední Evropa v dějinách. Praha: Academia.

Wolff, Larry. [1996]. Inventing Eastern Europe: The Map of Civilization on the Mind of the Enlightenment. Palo Alto: Stanford University Press.

Janowski, Maciej - Iordachi, Constantin - Trencsényi, Balázs. [2005]. Why Bother About Historical Regions? Debates Over Central Europe in Hungary, Poland and Romania. East Central Europe, 2005/1-2, s. $5-58$.

Stanislav Holubec působí na Universitě Friedricha Schillera v Jeně (SRN). Vydal dvě desítky článků $v$ odborných časopisech, je editorem sborníků Válka, mír a politická moc (2009) a Mladí, levice a rok 1968 (2010). Je autorem dvou monografí: Sociologie světových systémů. Hegemonie, centra, periferie (2009) a Lidé periferie. Sociální postavení a každodennost pražského dělnictva v meziválečné době (2009). 